\title{
Ebû Ubeyde b. Cerrâh'ın (ö. 18/639) Babasını Öldürdüğü ile İlgili Rivâyet Üzerine Bir Değerlendirme
}

\section{An Investigation About the Transmission that Abu Ubaydah b. Carrah (d. 18/639) Killed His Own Father}

\author{
Ali ARSLAN \\ Doç. Dr., Zonguldak Bülent Ecevit Üniversitesi, Illahiyat Fakültesi, Hadis Anabilim Dalı \\ Assistant Professor Zonguldak Bülent Ecevit University, Faculty of Theology, Department of Hadith \\ Zonguldak, Turkey \\ arslanalikarabuk@gmail.com \\ orcid.org/0000-0003-1085-9604
}

\author{
Makale Bilgisi / Article Information \\ Makale Türü / Article Types : : Araştırma Makalesi / Research Article \\ Geliş Tarihi / Received : : 11 Ekim / October 2020 \\ Kabul Tarihi / Accepted $\quad$ :05 Kasım / November 2020 \\ Yayın Tarihi / Published : : 15 Aralık / December 2020 \\ Yayın Sezonu / Pub Date Season : Aralık / December \\ Cilt / Volume: 7 - Sayı / Issue: 2 - Sayfa / Pages: 543-557 \\ Atıf / Cite as \\ Arslan, Ali. "Ebû Ubeyde b. Cerrâh’ın (ö. 18/639) Babasını Öldürdüğü ile Illgili Rivâyet Üzerine Bir Değerlendirme". \\ Bülent Ecevit Üniversitesi Ilahiyat Fakültesi Dergisi 7/2 (2020), 543-557. \\ Doi: 10.33460/beuifd. 809045 \\ İntihal / Plagiarism \\ Bu makale, en az iki hakem tarafından incelendi ve intihal içermediği teyit edildi. \\ This article has been reviewed by at least two referees and scanned via a plagiarism software. \\ Yayın Hakkı / Copyright ${ }^{\circ}$ \\ Zonguldak Bülent Ecevit Üniversitesi, İlahiyat Fakültesi tarafından yayınlanmıștır. Tüm hakları saklıdır. \\ Published by Zonguldak Bulent Ecevit University, Faculty of Theology, Zonguldak, Turkey. All rights reserved.
}

Öz: Resûlullah'ın (s.a.s.) risâlet devrinde meydana gelen ve bir sûrenin veya âyet/ âyetlerin inzâl olunmasına sebep olan hâdiseyi ve durumu ortaya koymak anlamında kullanılan sebebi nüzul, Kur'an'ın anlaşılmasında en önemli konulardandır. Bütün âyetler için böyle sebeplerden bahsetmek mümkün olmasa da en azından bir kısmının hangi sebebe binâen indiği ile ilgili farklı rivâyetler bulunmaktadır. Bu rivâyetlerin kabul edilmesinde öncelikli husus, bunların hadis usûlü kaidelerine uygun bir şekilde nakledilmesidir. Ayrıca sadece sened bakımından değil, aynı zamanda metin itibariyle de başta diğer âyetler olmak üzere, sahih sünnete, akla vb. aykırı olmamasıdır. Bu çalışmada Ebû Ubeyde b. Cerrâh'ın (ö. 18/639) Bedir Gazve'sinde babasını öldürmesi rivâyeti bu çerçevede ele alınmıştır. Öncelikli olarak ilgili rivâyetin hadis kaynaklarında nasıl geçtiği tespit edilmeye çalışılmıştır. Daha sonra ise tefsir kaynaklarındaki durumu ortaya çıkarılmıştır. Çünkü bu rivâyete yer veren kaynaklarda, burada anlatılan olay Mücâdele 58/22 âyetinin sebeb-i nüzûlü olarak gösterilmiştir. Bu arada Siyer kaynaklarında özellikle Bedir ve Uhud Gazvesi çerçevesinde anlatılan olaylar ile, bu rivâyette nakledilenler karşılaştırılmıştır. Çalışmada ilgili rivâyetin senedi hakkında bazı değerlendirmeler 
yapıldıktan sonra, tefsir kaynaklarındaki durumu ortaya konulmuştur. Netice olarak söz konusu rivâyet gerek sened, gerekse metin bakımından problemli olup, delil olarak kullanılmaya uygun değildir. Problemli rivâyetlerin kullanılmasının, olayları yanlış bir şekilde ortaya koymaya ve yanlış anlaşılmalara sebep olacağı ise aşikârdır.

Anahtar Kelimeler: Hadis, Ebû Ubeyde, Rivâyet, Baba, Öldürme.

Abstract: Occasion of the revelation used to reveal the incident and situation that occurred during the prophethood period of the Prophet (pbuh) and caused the cancellation of a surah or verse / verses is one of the most important issues in understanding the Quran. Although it is not possible to mention such reasons for all the verses, there are different transmissions based on what reason some of them were sent down. The primary issue in the acceptance of these transmissions is that they are conveyed in accordance with the rules of hadith methodology and in terms of the text, especially the other verses, sound sunnah, mind, etc. is not contrary. In this study, the transmission that Abu Ubaydah b. Carrah (d. 18/639) killed his father in the Gazwa of Badr is discussed in this context. It is seen that in many tafsir sources, the verse 58/22 of the Mujadala is linked to this narration. After making some evaluations about the sanad of the related narration, its situation in the tafsir sources was revealed. In the meantime, the events described in the Siyer sources, especially in the framework of the Battle of Badr and Uhud, and those reported in this narration were compared.As a result, it was concluded that the related transmission is problematic in terms of sanad and text and is not suitable to be used as evidence in this regard. It is emphasized that the use of problematic narrations is suitable for misunderstanding and portraying events in a wrong way.

Keywords: Hadith, Abu Ubaydah, Transmission, Father, Killed.

\section{Giriş}

Ebû Ubeyde Âmir b. Abdillâh b. el-Cerrâh el-Fihrî el-Kureşî (ö. 18/639), câhiliye devrinde dahi kendi kavmi tarafından hürmet gösterilen kişilerdendir. Müslüman olmasından sonra her türlü baskılara maruz kalmış, ilk önce Habeşistan'a daha sonra Medine'ye hicret etmiştir. Medine döneminde hemen her olayda bulunmuş ve bunların bir kısmında da önemli görevler üstlenmiştir. Bu çerçevede Bedir Gazvesi'ne de iştirak eden sahâbîlerden biri olmuştur.

Ebû Ubeyde'nin Bedir Gazvesi'ne katıldığında şüphe bulunmamakla birlikte, bazı rivâyetlerde bu gazvede ayrıca babasını öldürdüğü ile ilgili bilgiler bulunmaktadır. Bu nakillere göre o, Bedir Gazvesi'de müşrikler arasında bulunan babası ile karşılaşmak istememesine rağmen, babasının özellikle onun karşısına çıkması ve kendisine saldırması üzerine onu öldürmek zorunda kalmıştır. Bu olay üzerine ise, "Allah'a ve âhiret gününe iman eden bir topluluğun, Allah'a ve peygamberine düşmanlıkeden kimselere-babaları, oğulları, kardeşleriyahut diğer akrabaları da olsa- sevgiyle bağlandıklarını göremezsin. İşte Allah bu müminlerin 
kalplerine imanı nakşetmiş ve onları katından bir ruh ile desteklemiştir. Onları -orada ebedî kalmak üzere- altından ırmaklar akan cennetlere yerleştirecektir. Allah onlardan razı olmuştur, onlar da O'ndan razı olmuşlardır. İşte onlar Allah'tan yanadırlar; iyi bilinmeli ki kurtuluşa erecek olanlar da Allah'tan yana olanlardır"1 meâlindeki âyet-i kerime nâzil olmuştur. ${ }^{2}$ Bazı rivâyetlerde ise bu olay Uhud Gazvesi'nde gerçekleşmiş̧tir. ${ }^{3}$

Hiç şüphesiz Kur'ân-ı Kerim'in doğru anlaşılması ile vahyin indiği şartları ve ortamı bilme arasında çok sıkı bir ilişki bulunmaktadır. Bu çerçevede bazı âyetler, ibret alınması için geçmiş kıssalardan bahsetmiş, bir kısmı da yirmi üç yıllık nüzûl sürecinde meydana gelen bazı olayların açıklanması amacıyla inzâl edilmiştir. Bir kısmı ise belli bir sebebe bağlı olmaksızın inmiştir.

Başta müfessirler olmak üzere İslam âlimleri, âyetlerin sebebi nüzûlünü bilmenin, Kur'an'ı sahih bir şekilde anlayabilme konusundaki birçok faydası üzerinde durmuşlardır. Nitekim Sahâbe de daha sonraki dönemlerde âyetleri açıklarken öncelikli olarak sebeb-i nüzûlü göz önünde bulundurmuştur. Fakat sahâbe ve tâbiûnun bir âyetin sebeb-i nüzûlü olarak ortaya koydukları hususların gayesinin, o âyetin ifade ettiği hükmü açığa çıkarmak olması da mümkündür. Bu itibarla sebeb-i nüzûl ile ilgili rivâyetler hadis ilminin ortaya koyduğu kaidelere göre değerlendirildikten sonra, öncelikli olarak onların Kur'ân'ın bütünlüğü içerisinde değerlendirilmeleri gerekmektedir.

Bazı tefsirlerde sebeb-i nüzûl ile ilgili nakiller beraberce verilmekte, fakat bunlar arasında bir takım çelişkiler de bulunabilmektedir. Çoğu kere müfessirlerin herhangi bir tercihte bulunmadan naklettikleri bu rivayetler arasında, hangi esaslara göre tercih yapılacağı da önemli bir meseledir. Bu yapılmadığında delil olmaya elverişli olmayan rivâyetler, iyi niyetli olmayan şahıslar tarafından kullanılabilmektedir. Neticede zihinler karışmakta, doğru olmayan bilgiler yayılmakta ve insanlar arasında bu gibi konularda ihtilaflar artabilmektedir. Bu çalışmada buna örnek olarak gösterilebilecek bir rivâyet üzerinde durulacaktır. Nitekim bu rivâyet de kötü niyetliler tarafından gerektiğinde yakın akraba da olsa, onlara karşı bazı durumlarda kötü muâmele yapılabileceği yönünde kullanılmaya müsaittir. ${ }^{4}$ Bazı araştırmalarda kısmen işaret edilmekle birlikte bu rivâyet özelinde yapılan özel bir çalışmaya ise -yaptığımız kısa araştırma neticesindeulaşılamamıştır.

el-Mücâdele 58/22.

2 Ebu'l-Kâsım Süleymân b. Ahmed b. Eyyûb et-Taberânî, el-Mu'cemü'l-kebîr, thk. Hamdî b. Abdülmecîd es-Selefî (Kâhire: Mektebetü Ibn Teymiye, 1415/1994), 1/154-155.

3 Ebû Muhammed el-Hüseyn b. Mes'ûd el-Ferrâ' el-Begavî, Me'âlimü't-tenzîl, thk. Muhammed Abdullah en-Nemr, Osman Cum'a Damîriyye ve Süleyman Müslim el-Haraş (Riyâd: Dâru'd-tîbe, 1412/1991), 8/63.

4 Bu konuda yapılan bir uyarı için bk. Cerîdetü'l-Arabi'l-iktisâdiyyeti'd-düvelî (EL-IKTiSÂDî), "Makâlât" (Erişim 30 Eylül 2020). 


\section{Ebû Ubeyde b. el-Cerrâh'ın (ö. 18/639) Hayatı}

Hicretten yaklaşık olarak kırk yıl önce Mekke'de dünyaya gelen Ebû Ubeyde Âmir b. Abdillâh b. el-Cerrâh el-Fihrî el-Kureşî'nin soyu, onuncu dedesi olan Fihr'de Hz, Peygamber (s.a.s.) ile birleşmektedir. ${ }^{5}$ Benî Hâris kabilesine mensup olan Ebû Ubeyde'ye (r.a.), Mekke'de okuma yazma bilen az sayıdaki kişilerden olduğundan dolayı câhiliyye devrinde de Kureyşliler saygı göstermekteydi. O, Hz. Peygamber'in davetinin başladığı ilk günlerde Ebû Bekir'in aracılığıyla İslâm'a girmiştir. Müslüman olduktan sonra ise Kureyş tarafından yapılan her türlü baskıya maruz kalmasına rağmen, İslâmiyet'in yayılması için çalışmıştır.

Kendisine yapılan işkenceler artınca da diğer bazı sahâbîler gibi o da İkinci Habeşistan Hicret'ine iştirak etmiştir. ${ }^{6}$ Daha sonra Mekke'ye dönmüş ve Medine'ye hicret etmiştir. ${ }^{7}$ Medine'ye hicret eden muhâcirlerle, ensâr arasında kurulan kardeşlikte, Resûlüllah (s.a.s.) onu Sa'd b. Muâz (bazı rivâyetlerde Muhammed b. Mesleme ve Ebû Talha el-Ensârî) ile kardeş yapmıştır.

Resûlullah'la (s.a.s.) ile beraber başta Bedir ve Uhud olmak üzere gazvelerin tümüne katılan Ebû Ubeyde, Medine devrinde önemli görevlerde bulunmuştur. Uhud Gazvesi esnasında, Hz. Peygamber'in (s.a.s.) yanından ayrılmayan on dört kişiden biri de o olmuştu. Bazı gazvelerde kumandan tayin edilmiş, Mekke'nin fethinde Resûlullah'ın yanında bulunmuş, Hudeybiye anlaşmasında şâhid olarak ismi yazılmış, Yemen'e muallim olarak gönderilmiştir. Resûlullah ile dinî mevzularda münakaşa edip, cizye verme şartını kabul eden Necran heyeti, bu cizyeyi toplaması için güvenilir bir kişinin kendileriyle beraber gelmesini istediklerinde, Resûlüllah onu göndermiştir. Hatta bu istek üzerine "Her ümmetin bir emini vardır, bu ümmetin emini ise Ebû Ubeyde'dir" buyurmuştu. ${ }^{8}$ Sadece Necrânlıların değil bu bölgedeki diğer bazı kabilelerin de vergi toplama vazifesi kendine verilmiştir.

Hz. Ebû Bekir devrinde maliye işleri ve kumandanlık; Hz. Ömer devrinde de kumandanlık, valilik gibi görevlerde bulundu. Sahâbîlerden birçoğunun vefat ettiği "tâûnu Amvâs" olarak bilinen vebaya Beysân'a bağlı Amtâ köyünde yakalanmış ve burada defnedilmiştir.

Resûllullah'ın, Hz. Ebû Bekir ve Ömer'den sonra en çok sevdiğini belirttiği üçüncü kişi olan Ebû Ubeyde9, aynı zamanda cennetle müjdelenmişti. Hz. Ömer

5 Nesebi için bk. Taberânî, el-Mu'cemü'l-kebîr, 1/154-155; Ebû Nuaym el-İsfahânî, Ma'rifetü'ṣ-șahâabe, thk. Âdil b. Yûsuf (Riyâd: Dâru'l-vatan, 1419/1998), 1/148.

6 Ebû Abdillâh Muhammed b.İshâk, Sirretü Ibn İshâkk, thk. Süheyl Zekkâr (Beyrût: Dâru'l-fikr, 1398/1978), 226; İbn Hişâm, es-Sîretü'n-Nebeviyye, thk. Mustafa es-Sekkā - İbrâhim el-Ebyârî - Abdülhafîz eş-Şelebî (Mısır: Matbaatü Mustafa, 1375/1955), 1/329.

7 Ebû Nuaym, Ma'rifetü'ṣ-șaḥâbe, 1/148.

8 Müslim b. el-Haccâc b. Müslim el-Kuşeyrî, Șahị̣̂u Müslim, thk. Muhammed Fuâd Abdülbâkî (Beyrût: Dâru ihyâi'ttürâsi'l-Arabî, ts.), "Fedâilü's-sahâbe”, 53,54.

9 Ebû Îsâ Muhammed b. Îsâ b. Sevre et-Tirmizî, Süneni't-Tirmižî, thk. Ahmed Muhammed Şâkir-Muhammed Fuâd Abdülbâkî (Mısır, Şirketü Mektebeti ve Matbaati Mustafa, 1395/1975), “Menâḳıb”, 14. 
ise şayet hayatta olsa kendisinden sonra devlet başkanlığı için düşündüğü ismin Ebû Ubeyde olduğunu belirtmiştir. Hayatı daha çok muharebe meydanlarında geçen Ebu Ubeyde, aynı zamanda Kur'ân-ı Kerîm'i ezbere bilenlerdendir. Çok farklı görevlerde bulunması gibi sebeplerle kendisinden sadece on beş hadis nakledilmiştir. ${ }^{10}$

Hayatı hakkında kısa bilgi verilen Ebû Ubeyde'nin babasını öldürmek zorunda kaldığı ile ilgili rivâyetler ise bu araştırmanın asıl konusunu oluşturacaktır.

\section{Rivâyetin Hadis Kaynaklarındaki Durumu ve Değerlendirilmesi}

Ebû Ubeyde'nin babasını öldürmesi ile ilgili rivâyet, tespit edebildiğimiz kadarıyla hadis kaynaklarından Ma'mer b. Râşid'in (ö. 153/770) el-Câmi"i, İmâm Mâlik'in (ö. 179/795) el-Muvațța' ı, Abdullah b. Mübârek'in (ö. 181/797) Kitâbü'zZühd ve'r-rekā'ik'í, Ebû Yûsuf'un (ö. 182/798) Kitâbü'l-Âsâr'ı, İbn Vehb'nin (ö. 197/813) el-Câmi' fi'l-ḥadîs'i, Ebû Dâvûd et-Tayâlisî'nin (ö. 204/819) el-Müsned'i, eş-Şâfiî́nin (ö. 204/820) el-Müsned'i, el-Humeydî'nin (ö. 219/834) el-Müsned'i, Saîd b. Mansûr'un (ö. 227/842) es-Sünen'i, Ali b. el-Ca'd'ın (230/845) el-Müsned'i, İbn Ebî Şeybe'nin (ö. 235/849) el-Müsned'i, Ahmed b. Hanbel'in (ö. 241/855) elMüsned'i, Dârimî'in (ö. 255/869) es-Sünen'i, Kütübü Sitte, Bezzâr'ın (ö. 292/905) el-Müsned'i, İbn Huzeyme'nin (ö. 311/924) eṢ-Ṣahîh'̣'i, İbn Hıbbân'ın (ö. 354/965) Șaḥị̂’i gibi eserlerde yer almamaktadır.

Tespit edilebildiği kadarıyla bu rivâyet ilk olarak hadis eserlerinden Taberânî'nin (ö. 360/971) el-Mu'cemü'l-kebîr'inde geçmektedir:

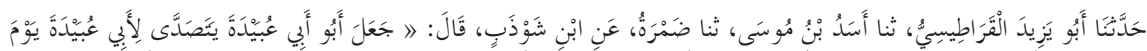

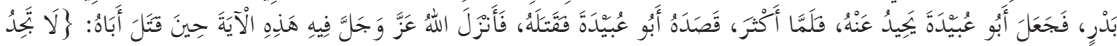

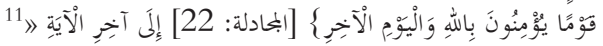

Senedi şu şekildedir: Ebu'l-Yezîd el-Karâdîsî-Esed b. Mûsâ-Damra- İbn Şevzeb.

(Bedir Gazve'si gününde Ebû Ubeyde'nin babası, Ebû Ubeyde'nin karşısına çıkmaya çalıştı. Ebû Ubeyde farklı yerlere geçse de, babası tekrar tekrar onun karşısına geldi. Neticede Ebû Ubeyde babasını öldürdü. Bunun üzerine de Mücâdele 58/22. âyet nâzil oldu).

$\mathrm{Bu}$ rivâyet doğrudan bir hadis eseri olmamasına rağmen, aynı sened ve metinle bir sahâbe biyografisi olan Ebû Nuaym el-i̇sfahânî'nin (ö. 430/1038) Ma'rifetü'ṣ-șahâbe isimli eserinde de nakledilmektedir:

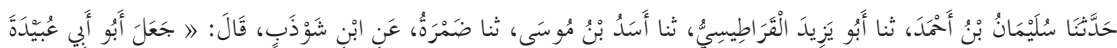

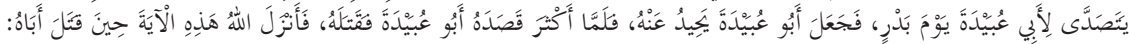

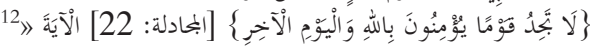

\footnotetext{
10 Hayatı hakkında bk. Taberânî, el-Mu'cemü'l-kebîr, 1/154-157; Ebü'l-Kāsım İbn Asâkir, Târîhu medîneti Dımaşk, thk. Amr b. Garâme el-Amrevî (Beyrût: Dâru'l-fikr, 1415/1995), 25/435-470; Ahmet Önkal, "Ebû Ubeyde b. Cerrâh", Türkiye Diyanet Vakfı İlâm Ansiklopedisi (İstanbul: TDV Yayınları, 1994), 10/249-250.

11 Taberânî, el-Mu'cemü'l-kebîr, 1/154-155.

12 Ebû Nuaym, Ma'rifetü'ṣ-șahâabe, 1/149.
} 
Sened: Süleymân b. Ahmed- Ebu'l-Yezîd el-Karâdîsî-Esed b. Mûsâ-Damra- İbn Şevzeb.

el-Hâkim en-Nîsâbûrî (ö. 405/1014) de, el-Müstedrek 'ale'ṣ-Ṣahîhayan'da yukarıdakilere benzer senetle rivâyet etmekle birlikte, metinde anlama etki etmeyecek bazı kelime farklılıkları ile aktarmaktadır:

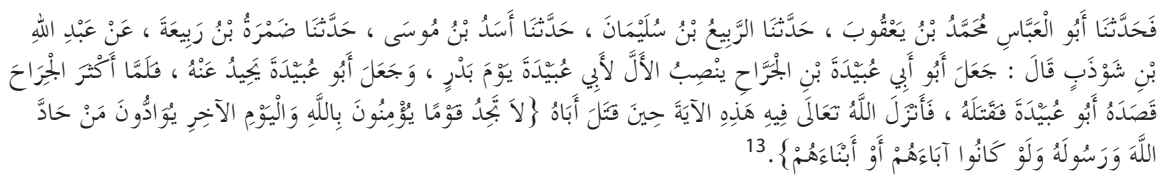

Sened: Ebu'l-Abbâs Muhammed b. Ya'kûb - er- Rebî' b. Süleymân - Esed b. Mûsâ-Damra b. Rebî'a - Abdullah b. Şevzeb.

Beyhakī (ö. 458/1066) es-Sünenül-kübrâ'da, el-Müstedrek'deki aynı isnadla hadisi nakletmektedir. Fakat rivâyetin sonunda, bunun münkatı' olduğunu belirtmektedir. ${ }^{14}$

İbn Hacer (ö. 852/1449) ise, Ebû Ubeyde'nin babasının ne zaman öldüğü ile ilgili bilgi vermeksizin, bu rivâyetin Taberânî ve diğerleri tarafından Abdullah b. Şevzeb tariki ile rivâyet edildiğini bildirmektedir. Abdullah b. Şevzeb'in hayatı hakkında açıklama yapmamakta, fakat bu rivâyetin mürsel olduğunu ifade etmektedir. ${ }^{15}$ Ayrıca İbn Hacer Telhișü̈l-ḥabîr'inde de, bu rivâyetin Abdullah b. Şevzeb tariki ile Hâkim ve Beyhakî tarafından rivâyet edildiğini, fakat bunun münkatı' bir senede sahip mu'dal hadis olduğunu belirtmektedir. Yine o, Vâkıdî'nin bu rivâyeti reddettiğini ve Ebû Ubeyde'nin babasının İslâm'dan önce vefat ettiğini bildirmektedir. ${ }^{16}$

Bu kaynaklarda zikredilen ve münkatı' olduğu belirtilen rivâyet için en önemli râvînin, Abdulah b. Şevzeb olduğu görülmektedir. Sâbit b. Eslem el-Basrî elBünânî (ö. 127/744), Hasan-ı Basrî (ö. 110/728), İbn Sîrîn el-Basrî (ö. 110/729) gibi tâbiînin önde gelenlerinden rivâyette bulunan Abddulah b. Şevzeb, hicrî 86 senesinde dünyaya gelmiş ve $156^{\prime}$ da ise vefat etmiştir. Dolayısıyla tebeu'ttâbiîn tabakasından olup, kendisinin öğrencileri arasında ise Damra b. Rebî’a, İbn Mübârek gibi âlimler bulunmaktadır. Kendisi hakkında İbn Sîrîn, İbn Hıbbân ve İbn Maîn gibi âlimler sika; Ebû Hâtim ise lâ be'se bih demektedir. ${ }^{17}$

13 Hâkim en-Nîsâbûrî, el-Müstedrek 'ale'ș-Șahîhayn, thk. Yûsuf el-Mar'aşlî (Beyrût: Dâru'l-ma'rife, 1406/1986), 3/26.

14 Ebû Bekr Ahmed b. el-Hüseyn el-Beyhakī, es-Sünenü'l-kübrâ, thk. Muhammed Abdülkâdir Atâ (Beyrût: Dârul'Ikütübü'l-ilmiyye, 1424/2003), 9/46.

15 İbn Hacer el-Askalânî, Fetḥu'I-bârî şerḥu Șahîhịi'I-Buhârî, thk. Muhibbüddin el-Hatîb v.dğr. (Beyrût: Dâru'l-ma'rif, 1379), 7/93.

16 İbn Hacer el-Askalânî, Telhị̦̂̈̈'l-ḥabîr fi tahrî̀ci eḥâdîsii'r-Râfi'iyyi'l-kebîr, thk. Ebû Âsım Hasan b. Abbâs (Mısır: Müessesetü Kurtuba, 1416/1995), 4/192.

17 Ebû Abdillâh Şemsüddîn Muhammed b. Ahmed ez-Zehebî, Siyeru a'lâmi'n-nübelâ', thk. Şuayb el-Arnaût ve dğr. (Beyrût: Müessesetü'r-risâle, 1405/1985), 7/92-93); i ibn Hacer, Tehżîbü't-Tehzîib, 5/255. 
Zehebî de (ö. 748/1348), Evzâî tabakasından olarak zikrettiği Abdullah b. Şevzeb için sadûk ve imâm nitelemesinde bulunmaktadır. Ayrıca ondan, Sünen sahiplerinin rivâyette bulunduğunu ifade etmekte, peşinden ise onun meçhul birisi olduğunu söylemektedir. ${ }^{18}$ İbn Hacer Lisânü'l-Mizân'ında Abdullah b. Şevzeb hakkında, sika, sadûk gibi ifadeler kullanmakta, onun hakkında sadece İbn Hazm'ın meçhûl dediğini bildirmektedir. ${ }^{19}$

Netice itibariyle Abdullah b. Şevzeb hakkındaki ifadeler genel itibariyle onun güvenilirliği yönünde olmaktadır. Fakat kendisi tebeu't-tâbiîn tabakasından olduğundan, rivâyetin senedi muttasıl değildir. Nitekim yukarıdaki eserlerin bir kısmında da buna işâreten, senedin munkatı veya mu'dal olduğu belirtilmiştir. Senedi munkatı rivâyetlerin ise merdûd olduğu, hadisçiler arasında kesin olan hususlardandır. ${ }^{20}$

Ebû Ubeyde'nin babasını öldürdüğü bildirilen gazve, Bedir veya bazı rivâyetlerde de aşağıda belirtileceği üzere Uhud gazvesi olarak geçmektedir. Burada siyer kaynaklarında böyle bir bilginin bulunup bulunmadığı da önem kazanmaktadır. Siyer ve İslam Tarihi kaynaklarına bakıldığında bu bilgiyi teyit edecek bir nakil bulunmamaktadır. Mesela Vâkıdî (ö. 207/823) ve İbn Hişâm (ö. 218/833) gerek Bedir, gerekse Uhud'da öldürülen müşriklere ayırdıkları bölümlerde böyle bir isimden bahsetmemektedirler. ${ }^{21}$

Bazı tarih kitaplarında ise bu bilgiye rastlamak mümkündür. Mesela İbn Asâkir (ö. 571/1176) yukarıdaki rivâyetleri sıraladıktan sonra senedle ilgili olarak bir değerlendirme yapmadan, bu rivâyete yer vermektedir. Fakat o, bu nakillerin peşinden Ebû Ubeyde'nin babasının İslâm devrine yetiştiği ve Ebû Ubeyde'nin onu savaşta öldürdüğü ile ilgili bilgileri Vâkıdî́nin reddettiğini nakletmektedir. Yine o, Vâkıdî'den Ebû Ubeyde'nin babasının İslâm gelmeden önce vefat ettiği ile ilgili bir habere yer vererek bu görüşü desteklemektedir. ${ }^{22}$ Bu bilgilerin hepsi bir arada düşünüldüğünde ilgili rivâyetin gerek metin, gerekse sened açısından problemli olduğu ve delil olarak kullanılabilecek kuvvette olmadığı ortaya çıkmaktadır.

\section{Rivâyetin Tefsir Kaynaklarındaki Durumu}

Mücâhid b. Cebr'e (ö. 103/721) nispet edilen, Tefsîru Mücâhid'de bu âyetle ilgili olarak herhangi bir rivâyete işaret edilmemektedir. ${ }^{23}$ Kur'an'ı Kerim'i baştan

18 Ebû Abdillâh Şemsüddîn Muhammed b. Ahmed ez-Zehebî, Mîzânü'l-i'tidâl, Ali Muhammed Muavvaz - Âdil Ahmed Abdülmevcûd (Beyrût: Dâru'l-kütübi'l-ilmiyye, 1416/1995), 4/120.

19 İbn Hacer el-Askalânî, Lisânü'l-Mîzân (Beyrût: Müessesetü'l-a'lamî, 1390/1971), 7/264.

20 bk. İbn Hacer el-Askalânî, Nüzhetü'n-naẓar fí tavżịhi Nuhbeti'l-fiker, thk. Abdullah b. Dayfullah (Riyâd: Matbaat-ü sefîr, 1429/2008), 96, 100-101.

21 Ebû Abdillâh Muhammed el-Vâkıdî, Megāzî, thk. Marsden Jones (Beyrût: Dâru'l-a'lemî, 1409/1989), 1/147-152, 307-319; İbn Hişâm, es-Sîretü'n-nebeviyye, 1/708-716, 2: 127-129.

22 İbn Asâkir, Târîhu medîneti Dımaşk, 25/447.

23 Mücâhid b. Cebr, Tefsîru Mücâhid, thk. M. Abdüsselâm Ebü'n-Nîl' (Mısır: Dâru'l-fikr, 1410/1989), 651. 
sona tefsir eden ve tefsiri günümüze kadar ulaşan ilk müfessir olarak kabul edilen Mukātil b. Süleymân'ın (ö. 150/767), Tefsîru Mukātil b. Süleymân'ında ise bu âyetin sebebi nüzûlü olarak herhangi bir sened zikredilmeksizin, sadece âyetin Hâtıb b. Ebî Beltea (ö. 30/650) hakkında inzâl edildiği bilgisi bulunmaktadır. ${ }^{24}$ Süfyân es-Sevrî'nin (ö. 161/778) Tefsîru Süfyâni'ș-Sevrî, Yahyâ b. Sellâm'ın (ö. 200/815) Tefsîru Yaḥyâ b. Sellâm gibi eserlerinde ise bu eserlerin tam olarak günümüze ulaşmaması gibi sebeplerle, bu sûrenin tefsiri bulunmamaktadır. Taberî (ö. 310/923) Câmi'u'l-beyân 'an te'vîli âyi'l-Kur'ân'ında bu konuda genel bir ifade kullanmakta ve âyetin ilgili kısmı "Şayet Allah ve Resûlüne düşmanlık edenler, onların babaları dahi olsa" ifadeleriyle açıklanmaktadır. Bu konuda herhangi bir rivâyete yer verilmemektedir. ${ }^{25}$ Mâtürîdî (ö. 333/944) Te'vîlâtü Ehli's-sünne'sinde ise isim zikretmeksizin te'vil ehlinin çoğunluğunun bu âyetin Hâtıb b. Ebî Beltea hakkında nâzil olduğunu söylediklerini nakletmektedir. ${ }^{26}$

Bulunabildiği kadarıla rivâyet öncelikli olarak ilk dönem tefsirlerinden olmayan Sa'lebî'nin (ö. 427/1035) el-Keşf ve'l-beyân 'an tefsîri'l-Kur'ân isimli tefsirinde geçmektedir. O, Mücâdele 58/22 âyetinin tefsirinde, bu âyetin sebebi nüzûlu olarak birçok rivâyet aktarmıştır. Bunlardan bir tanesi de bu âyetin, Ebû Ubeyde b. Cerrâh'ın babasını Uhud'da öldürmesi hakkında indiği ile ilgilidir. O, ayrıca bu öldürme olayının Bedir Gazvesi'nde olduğu ile ilgili bilgiye temrîz sîgası ile işaret etmektedir. Bu rivâyeti değerlendirme amacıyla ise Vâkıdî'den alıntı yapmaktadır. Buna göre Vâkıdî, Beni'l-Hâris b. Firh'den bir takım kişilere bu durumu sorduğunda onlar, Ebû Ubeyde'nin babasının İslâm'dan önce vefat ettiğini haber vermişlerdir. Bu rivâyetle ilgili olarak Vâkıdî bu değerlendirmeyi yapmasına rağmen, âyetin "Babaları olsa bile" kısmını tefsir ederken Ebû Ubeyde'yi örnek vermektedir. Örnek verdiği yerde ise herhangi bir değerlendirmede bulunmamaktadır. ${ }^{27}$

el-Mâverdî (ö. 450/1058) Tefsîrü'l-Ḳur'ân (en-Nüket ve'l-'uyûn)'nında ilgili âyetin tefsirinde, bu âyetin kimin hakkında indiğinde ihtilaf edildiğini ve bu konuda üç görüş bulunduğunu bildirmektedir. Bunlardan birincisi olarak ise, İbn Şevzeb'in yukarıdaki rivâyetini nakletmektedir. Senedin geri kalanını ayrıca zikretmediği gibi, senetle ilgili olarak bir değerlendirme de yapmamaktadır. ${ }^{28}$

24 Mukātil b. Süleymân, Tefsîru Mukātil b. Süleymân, thk. Abdullah Mahmûd Şehhâte (Beyrût: Daru ihyâi't-turâs, 1423), 4/265-266.

25 Ebû Ca'fer Muhammed b. Cerîr et-Taberî, Câmi'u'I-beyân 'an te'vîli âyi'I-Kur'ân, thk. Abdullah b. Abdülmuhsin etTürkî (Kâhire: 1422/2001), 22/493.

26 Ebû Mansûr Muhammed et-Mâtürîdî, Te'vîlâtü Ehli's-sünne, thk. Mecdî Basellûm (Beyrût: Dârü'l-kütübi'lilmiyye, 1426/2005), 9/528.

27 Ebû İshâk Ahmed b. Muhammed es-Sa'lebî, el-Keşf ve'I-beyân 'an tefsîri'l-Ḳur'ân (Cidde: Dâru't-tefsîr, 1436/2015), 26/167-168.

28 Ebü'l-Hasen Alî b. Muhammed el-Mâverdî, Tefsîrü'l-Ḳur'ân (en-Nüket ve'I-'uyûn), thk. Seyyîd b. Abdülmaksûd b. Abdürrahîm (Beyrût: Dâru'l-kütübi'l-ilmiyye, ts.), 5/495. 
Sa'lebî'nin tefsirinin bir muhtasarı olarak da görülen Begavî́nin (ö. 516/1122) Me'âlimü't-tenzîl'inde de bu rivâyet yer almaktadır. Bilindiği üzere Me'âlimü't-tenzîl telif edildikten sonra, çok itibar görmüş ve kendinden sonraki eserlere kaynaklık etmiştir. Bu konuda Hâzin'in Lübâbü't-te'vîl fî me'âni't-tenzîl'i, İbn Kesîr'in Tefsîrü'lKur'âni'l-'ạ̣îm'i örnek olarak zikredilebilir.

BegavîMe'âlimü't-tenzîl'de, Mücâdele süresi 22. âyetin tefsirinde, farklı olaylara işaret etmekle birlikte, Mükâtil b. Hayyân (ö. 150/767) - Mürre el-Hemedânî (ö. 99/708) - Abdullah b. Mes'ûd'dan (ö. 32/652-53) bu âyet ile ilgili olarak şunu nakletmektedir: "Bu âyetin "Şayet babaları bile olsa" kısmı, Uhud gazvesinde babasını katleden Ebû Ubeyde b. Cerrâh hakkında inmiştir..."29 Begavî tefsirle ilgili rivâyetleri hangi yollarla aldığını mukaddimede zikrettiğinden burada rivâyeti bu şekilde zikretmiş, peşinden herhangi bir değerlendirmede bulunmamıştır.

Zemahşerî'nin (ö. 538/1144) el-Keşşâf'ında bu âyetin sebebi nüzûlü ile ilgili olarak zikrettiği olaylar içinde, temrîz sîgası ile bu rivâyete yer vermekte, fakat bu olayın Uhud'da olduğunu bildirmektedir. Bu rivâyetle ilgili olarak ayrıca bir sened zikretmemekte veya değerlendirmede bulunmamaktadır. ${ }^{30}$

Kurtubî (ö. 671/1273) el-Câmi' li-aḥkâmi'l-Kurân isimli eserinde ilgili âyetin tefsirinde, farklı rivâyetleri naklettikten sonra, İbn Mes'ûd'un bu âyetin Ebû Ubeyde hakkında indiği ile ilgili sözünü nakletmektedir. Sonra da bu konu ile ilgili olarak Vâkıdî'den onun babasının İslâm'dan önce öldüğü ile ilgili bilgiyi aktarmaktadır. ${ }^{31}$ Rivâyetin senedi ve metni hakkında ise başka bir izah yapmamaktadır.

Hâzin'in (ö. 741/1341) Lübâbü't-te'vîl fî me'âni't-tenzîl'inde de benzer şekilde geçmektedir. Hâzin kimin naklettiğini belirtmeksizin, meçhûl sîga ile "Abdullah b. Mes'ûd'dan rivâyet edildiğine göre" diyerek bu bilgiyi zikretmektedir. Buna göre, ilgili âyetin "Şayet babaları bile olsa" kısmı, Bedir'de babasını öldüren Ebu Ubeyde b. Cerrâh hakkında inmiştir. ${ }^{32}$ Onun temrîz sığası ile bu bilgiyi nakletmesi aynı zamanda, bu nakle tam güvenmediğinin de bir işaretidir.

İbn Kesîr (ö. 774/1373) Tefsîrü'I-Kur'âni'l-'ạ̣îm'de bu âyetin tefsirinde, Saîd b. Abdülazîz ve isim vermeden başka kişilerden naklederek, bu âyetin Ebû Ubeyde b. Cerrâh'ın Bedir'de babasını öldürmesi üzerine nâzil olduğunu bildirmektedir. Sened ve metin ile ilgili olarak ise herhangi bir açıklama yapmamaktadır. Fakat bu sebepten dolayı, Hz. Ömer'in kendisinden sonra halifelik için altı kişiyi aday gösterdiğinde, "Şayet Ebû Ubeyde hayatta olsaydı, onu halef tayin ederdim." dediğini nakletmektedir. ${ }^{33}$

29 Begavî, Me'âlimü't-tenzîl, 8/63.

30 Ebü'l-Kāsım Mahmûd b. Ömer ez-Zemahşerî, el-Keşşâf 'an ḥakāâiki't-tenzîl, thk. Abdurrezzâk el-Mehdî (Beyrût: Daru ihyâi't-turâs, ts.), 4/457.

31 Ebû Abdillâh Muhammed b. Ahmed el-Kurtubî, el-Câmi' li-ahkâmi'l-Kur'ân, thk. Ahmed el-Burdûnî (Kâhire: Dâru'l-kütübi'l-Mısriyye, 1384/1964), 17/307.

32 Ebü'I-Hasen Alâüddîn Alî b. Muhammed el-Hâzin, Lübâbü't-te'vîl fîme'âni't-tenzîl' (Beyrût: Dâru'l-fikr, 1399/1979), $7 / 54$.

33 Ebü'l-Fidâ' İmâdüddîn İsmâîl İbn Kesîr, Tefsîrü'l-Kur'âni'l-'aẓîm, thk. Sâmî b. Muhammed es-Selâme (B.y. Dâru Tayyibe, 1420/1999), 8/54. 
Suyûtî (ö. 911/1505) de ilgili âyetin tefsirinde, İbn Ebû Hâtim, Taberânî, Hâkim, Hilye'sinde Ebû Nuaym, Sünen'inde Beyhakî ve İbn Asâkir'in, Abdullah b. Şevzeb kanalıyla bu rivâyeti naklettiklerini bildirmektedir. Burada da herhangi bir değerlendirme bulunmamaktadır. ${ }^{34}$

Sa'lebî öncesi müfessirler tarafından ilgili âyetin tefsirinde Ebû Ubeyde b. Cerrâh'ın babasını öldürdüğü ile ilgili bir bilgi bulunmamaktadır. Bu âyetin tefsirinde, bu kıssaya da yer verilmeye başlaması Sa'lebî'den sonrasına denk gelmektedir. Burada dikkat çeken diğer bir husus ise, daha sonraki müfessirler bu âyeti tefsir ederken, diğer birçok rivâyetin yanında bu kıssaya da yer vermişlerdir. Senette Abdullah b. Şevzeb'in adının geçtiği rivâyetlerin delil olmaya elverişli olmadığı yukarıdaki bölümde geçmişti. Bu rivâyetle ilgili olarak zikredilen ikinci tarîk olan, Mükâtil b. Hayyân - Mürre el-Hemedânî - Abdullah b. Mes'ûd senedi için de benzeri şeyleri söylemek mümkündür. Öncelikli olarak bu rivâyetin senedi birçok tefsirde tam olarak geçmemektedir. Bu tariki zikredenler ise senetle ilgili bir değerlendirme yapmamışlar. Sadece metin tenkidi olarak Ebû Ubeyde'nin babasının İslâm'dan önce vefat ettiği ile ilgili nakillere yer vermişlerdir. Bu senetteki râvîler hakkındaki ricâl edebiyatında ise genel itibariyle sika denilmektedir:

Zehebî tarafından âbid ve sâhibi sünnet biri olarak tanıtılan Mükâtil b. Hayyân'ı (ö. 150/767), Yahyâ b. Maîn ve Ebû Dâvûd sika olarak nitelemişlerdir. Yine Nesâî onun hakkında "leyse bihî be's" derken, Ahmed b. Hanbel de onu önemsiz biri olarak görmektedir. Hocaları arasında Saîd b. Müseyyeb, Ebû Bürde b. Ebî Mûsâ, İkrime, Sâlim b. Abdullah, Katâde, Dahhâk, Ömer b. Abdülaziz bulunmaktadır. Talebeleri arasında ise Mus'ab b. Hayyân, Abdullah b. Mübârek, Bikr b. Ma'rûf gibi çok sayıda âlim bulunmaktadır. ${ }^{35}$ Nitekim Begavî onun tefsirini Bikr b. Ma'rûf vasıtasıyla aldığını bildirmektedir. ${ }^{36}$

Mürre el-Hemedânî ise tâbiînin büyüklerinden olup, İbn Ömer, Berâ', İbn Mes'ûd gibi sahâbîlerden rivâyette bulunmuş olup, kendisinden de A'meş, Mansûr b. Mu'tebir, Ebû İshâk gibi âlimler rivâyette bulunmuştur. İbn Maîn, Ebû Zur'a, Nesâî kendisi hakkında sika demişler ve İbn Hıbbân Sikât'ında zikretmiştir. Bazıları onun Ömer b. Abdülazîz devrinde vefat ettiğini, bazıları ise vefat tarihinin 99 veya 82 olduğunu ileri sürmüşlerdir. ${ }^{37}$

Burada dikkat çeken önemli bir husus ise Mürre el-Hemedânî'nin talebeleri arasında Mukâtil b. Hayyân'a yer veren herhangi birisinin bulunmamasıdır.

34 Ebü'l-Fazl Celâlüddîn es-Süyûtî, ed-Dürrü'l-mensûr fi't-tefsîr bi'l-me'șûr, thk. Abdullah b. Abdülmuhsin et-Türkî (Kâhire: 1424/2003), 14/328-329.

35 Zehebî, Mîzânü'l-i'tidâl fî naḳdi'r-ricâl, thk. Ali Muhammed el-Bicâvî (Beyrût: Dâru'l-ma'rife, 1382/1963), 4/171172; ỉbn Hacer el-Askalânî, Tehżîü̈'t-Tehżîb (Hind: Matbaatü dâireti'l-me'ârif, 1326), 10/277-279.

36 Begavî, Me'âlimü't-tenzîl,1/36.

37 Ebü'l-Haccâc Cemâlüddîn el-Mizzî, Tehžîü̈l-Kemâlfîesmâ'i'r-ricâl, thk. Beşşâr Avvâd Ma'rûf (Beyrût, Müessesetü'rrisâle, 1400/1980), 16/114-115; İbn Hacer, Tehżîbü't-Tehżîb, 6/24; Moğultay b. Kılıç, İkmâlü Tehżîbi'l-Kemâl,thk. Âdil b. Muhammed, Üsâme b. İbrâhim (Kâhire: el-Fârûku'l-hadîsiyye, 1422/2001), 8/191-193. 
Ayrıca hocaları arasında İbn Mes'ûda işaret eden olduğu gibi hiç zikretmeyenler de bulunmaktadır. Aynı durum Mükâtil b. Hayyân için de geçerlidir ki, onun da hocaları arasında Mürre zikredilmemektedir. ${ }^{38}$ Mürre kibâr-i tabiînden olup, Mükâtil b. Hayyân'ın rivâyetleri ise daha çok "evsât-ı tâbiîn" ve "sıgār-ı tâbiîn" dendir. Bu durum ise kesin olmamakla birlikte senette bir kopukluğa da işaret etmektedir.

\section{Rivâyetin İlgili Âyet Çerçevesinde Değerlendirilmesi}

Ebû Ubeyde'nin babasını öldürdüğünü ifade eden rivâyetlerde, bu olayın geçtiği gazve olarak bazılarında Bedir, bir kısmında ise Uhud geçmektedir. Bu gazvelerden Bedir'in hicrî ikinci senede, Uhud'un ise üçüncü senede meydana geldiği ile ilgili olarak herhangi bir tereddüt yoktur. Bu olayın irtibatlandırıldığı âyet ise Mücâdele süresinin 22. âyetidir. Bu süre de çoğunluğun görüşüne göre Medenî'dir. ${ }^{39}$ Nuzûl sıralaması bakımından da genelde Medine döneminin sonlarına doğru inen süreler arasında sayılmaktadır. Mesela tâbiûn âlimlerinden Câbir b. Zeyd'in (ö. 93/711-12) yapmış olduğu tertipte -ki bu tertip, rivâyet tertiplerinde zikredilen neredeyse eksiksiz ender listelerdendir- sondan dokuzuncu sıradadır. ${ }^{40}$ Mücâdele süresi üzerine yapılan bir çalışmada ise nüzûl tarihi olarak hicrî beşinci yıl ile dokuzuncu yıllar arası tespiti yapılmıştır. ${ }^{41}$

Bilindiği üzere bir hâdisenin sebeb-i nüzûl olarak kabul edilebilmesi en başta, ilgili bilginin nakledildiği rivâyetin, hadis usûlü ilminde tespit edilen kâidelere uygunluğu şartına bağlıdır. Çünkü bu durum ancak, âyetin indiği andaki duruma bizzat şahitlik etmiş bir sahâbînin nakli ve bu naklin de muttasıl bir senetle rivâyetiyle mümkün olabilir. Bu temel şartın yanında ilgili âyetin veya sûrenin indiği tarih ve yerin bilinmesi de önem arz etmektedir. İlgili âyetin nüzûl tarihi dikkate alındığında, bu olayın daha erken bir devirde meydana geldiği söylenebilir. Dolayısıyla bu âyetin veya ilgili kısmının bu sebebe binâen indiğinin ifade edilmesi zor görülmektedir.

Kur'ân'ın tefsirinde birinci sıra, yine Kur'ân-ı Kerim'in kendisi olduğundan ilgili âyetler birlikte düşünülmelidir. Bu çerçevede bakıldığında ilgili âyetin, anne ve babaya itaatten bahseden âyetlerin muhtevası ile beraber düşünülmesi de ayrıca bir zorunluluktur.

Anne ve babaya güzel muamele edilmesi konusu âyetlerde özellikle üzerinde durulan ve bu itibarla da İslam ahlakının en önemli kurallarından biri olmaktadır. Fakat burada en hassas çizgi, anne ve babanın verdiği emrin, şirk kapsamına giren bir husus olmamasıdır. Bu durumda onlara itaat edilmesi gibi bir durum

38 Mizzî, Tehżîbü'l-Kemâl fi esmâ'i'r-ricâl, 16/114-115; İbn Hacer, Tehzîibü't-Tehzîib, 10/277-279.

39 Kurtubî, el-Câmi'li-ahkâmi'l-Kur'ân, 17/269.

40 Ebü'l-Fazl Celâlüddîn es-Süyûtî, el-Itțān fî 'ulûmi'l-Kur'ân (Suûdiyye: Mecmeu'l-Melik Fahd, ts.), 1/168-169.

41 Nursel Çelik, Temel Konuları Bağlamında Mücâdele Süresi ve Tefsiri (İstanbul: İstanbul Üniversitesi, Sosyal Bilimler Enstitüsü, Yüksek Lisans Tezi, 2011), 9-10. 
söz konusu olmamaktadır. Nitekim aşağıdaki âyetler bu konuyu çok net olarak ortaya koymaktadır.

"Biz insana anne ve babasına güzel davranmasını tavsiye ettik. Eğer onlar, hakkında bilgi sahibi olmadığın bir şeyi bana şirk koşman için seni zorlarlarsa onlara itaat etme. Dönüşünüz banadır. Ben de size, yaptığınız şeyleri haber vereceğim." 42

“Biz insana anne babasıyla ilgili tavsiyeler verdik. Annesi, onu zorluklar içinde karnında taşımıştır; onun sütten ayrılması iki yıl içindedir ki bana ve anne babana teşekkür etsin. Dönüş banadır. Eğer onlar, hakkında bilgi sahibi olmadığın bir şeyi bana şirk koşman için seni zorlarlarsa onlara itaat etme. Onlara dünyada iyi davran. Bana yönelen kimsenin yoluna tabi ol. Sonra dönüş banadır. Ben size, yaptığınız şeyleri haber vereceğim." ${ }^{\prime 43}$

Âyetler, anne ve babanın çocuklarına şirki emretmeleri durumu hâriç, müşrik de olsalar onlara itaati emretmektedir. Çünkü çocuklar üzerinde ebeveynin hakkı çok büyüktür. Onların şirk koşmaları, çocuklarını büyütürken katlandıkları zorluklardan dolayı hak ettikleri iyiliği yok etmez. ${ }^{44}$ Müşrik olan anne ve babaya karşı bile bu şekilde davranılması emir edilirken, başka bir rivâyette Ebû Ubeyde'nin babasını öldürmüş olmasının övülmesi bir biri ile uyumlu olarak da gözükmemektedir.

Mücadele süresine genel olarak bakıldığında, üç konuya değinildiği görülmektedir: İlk dört âyet zıhâr, sonraki dokuz âyet yahudilerin bazı özellikleri ve bundan sonraki âyetler de yahûdîlerle dostluk kurup Müslüman gibi görünen münâfıklar hakkındadır. Bu açıdan son âyette zikredilen, Müslümanların kendilerine karşı sevgi beslemeyeceği kimselerin öncelikle yahûdî, münâfık ve müşrikler olduğu açıktır. Ayrıca bu kimselere karşı sevgi beslenilmeyeceğinden bahsedilmektedir, onların öldürülmesi gibi bir husus üzerinde durulmamaktadır. Nitekim bu konu ile ilgili olarak zikredilmesi gereken Âl-i İmrân 3/28, Mâide 5/51, 55, 57, Enfâl 8/73, Tevbe 9/23, Mümtehıne 60/1, 9 gibi âyetlerde de de aynı muhteva işlenmektedir. Bundan dolayı mezkûr âyetteki maksadı, Fahreddin Râzî (ö. 606/1210) şu şekilde açıklamıştır: Baba, oğul, kardeş gibi kişilere karşı sevgi beslemek, sevgilerin en büyüguüdür. Fakat bu kimseler Allah'a ve Resûlü'ne muhâlefet ederlerse, o takdirde mü'min kişinin sahip olduğu imanından dolayı, onlara beslediği sevgiyi terk etmesi gerekir. ${ }^{45}$

Bu rivâyet çerçevesinde Bedir Gazve'sinde Ebû Huzeyfe (ö. 12/633) ve müşrik safında yer alan babası Utbe arasında cereyan eden hadiseler de birlikte

42 Ankebût 29/8.

43 Lokmân 31/14-15.

44 Kurtubî, el-Câmi' li-ạ̣kâmi'l-Kur'ân, 14/63-65.

45 Fahrüddîn Muhammed b. Ömer b. Hüseyn er-Râzî, Mefâtîhu'l-ġayb (Beyrût: Daru ihyâi't-türâsi'l-Arabî, 1420), 29/499-500. 
düşünülmelidir. O, babasını çok seven birisi olarak, onun isabetli görüşlülüğü sayesinde bir gün Müslüman olacağını ümit etmekteydi. Bedir Gazve'sinde onu karşı tarafta görünce bundan dolayı çok üzülmüştü. Gazvenin başında onu mübârezeye davet etti, fakat Resûlullah (s.a.s.) buna izin vermedi. Gazve neticesinde müşriklerin atıldığı kuyuya, babası da atıldı. Hatta Resûlullah (s.a.s.) onların cesetlerinin gömüldüğü kuyunun başına varıp, Utbe dâhil ileri gelenlerinin ismini söylerek “...Allah'ın size vaat ettiği azaba ulaştınız, ben ise Rabbimin bana vaat ettiği zafere nâil oldum." buyurdu. Babasına İslam nasip olmadan öldüğünden dolayı üzülen Ebû Huzeyfe için ise, hayır duada bulundu. ${ }^{46}$

\section{Sonuç}

İslam âlimleri sâdık haberi, akıl ve havâss-ı selime ile birlikte bilgi elde etme yollarından biri olarak kabul etmişlerdir. Haberin kabul edilebilmesi için de sened ve metni ilgilendiren birçok kaide ortaya koymuşlardır. Bu şartları taşımayan haberlerin ise dikkate alınmaması gerektiğini açık bir şekilde belirtmişlerdir. Özellikle haberlerin bir çeşidi olan hadisler konusunda bu durum daha bir önem arz etmektedir. Çünkü hadislerle elde edilen bilgi dinî konu ile alakalı olduğundan, hadislerin kabulü için gerekli şartların bulunmaması, dini yanlış anlama ve yorumlama gibi durumlara sebebiyet vermektedir.

Bu çalışmada Ebû Ubeyde b. Cerrâh'ın (r.a.) Bedir veya Uhud Gazve'sinde babasını öldürdüğü ile ilgili olarak nakledilen rivâyet ele alınmıştır. Bu rivâyetin bazı müfessirlerce özellikle Mücâdele 58/22. âyetinin tefsirinde zikredilmesi sebebiyle, tefsir kaynaklarına da müracaat edilmiştir.

İlgili rivâyet öncelikli olarak hadis kaynaklarında araştırılmış ve gerek sened, gerekse metin açısından delil olarak kullanılmaya elverişli olmadığı sonucuna ulaşılmıştır. Tefsir kaynakları üzerinde yapılan araştırmada da benzeri neticeler elde edilmiştir.

Bu tarz rivâyetlerin dinî heyecanı artırmak için kullanılması mümkün olduğu gibi, iyi niyetli olmayan kişiler tarafından da suiistimal edilmesi o derece mümkündür. Ölçü ise haberin gerekli şartları taşıdığının tespitinden sonra, Kur'ân ve sünnetin muhtevasına uygunluğunun araştırılmasıdır.

46 Müslim, “Cennet", 76-77; Ebü'l-Hasen İzzeddin İbni'I-Esîr, Üsdü'l-gābe' fî ma'rifeti'Ṣ-Șahâhbe, thk. Ali Muhammed Mu'avvaz - Âdil Ahmed Abdülmevcûd (Beyrût: Dârü'l-kütübi'l-ilmiyye, 1994), 6/68. 


\section{Kaynakça}

Begavî, Ebû Muhammed el-Hüseyn b. Mes'ûd el-Ferrâ'. Me'âlimü't-tenzîl. thk. Muhammed Abdullah en-Nemr, Osman Cum'a Damîriyye, Süleyman Müslim el-Haraş. 8 Cilt. Riyâd: Dâru'd-tîbe, 1412/1991.

Beyhakî, Ebû Bekr Ahmed b. el-Hüseyn. es-Sünenü'l-kübrâ. thk. Muhammed Abdülkâdir Atâ. 10 Cilt. Beyrût: Dârul'I-kütübü'l-ilmiyye, 1424/2003.

Çelik, Nursel. Temel Konuları Bağlamında Mücâdele Süresi ve Tefsiri. İstanbul: İstanbul Üniversitesi, Sosyal Bilimler Enstitüsü, Yüksek Lisans Tezi, 2011.

Ebû Nuaym el-İsfahânî. Ma'rifetü'Ṣ-Șaḥâbe. thk. Âdil b. Yûsuf. 7 Cilt. Riyâd: Dâru'l-vatan, $1419 / 1998$.

el-Hâkim en-Nîsâbûrî. el-Müstedrek 'ale'Ș-Ṣahịhayn. thk. Yûsuf el-Mar'aşlî. 4 Cilt. Beyrût: Dâru'l-ma'rife, 1406/1986.

Hâzin, Ebü'l-Hasen Alâüddîn Alî b. Muhammed. Lübâbü't-te'vîl fî me'âni't-tenzîl'. 7 Cilt. Beyrût: Dâru'l-fikr, 1399/1979.

İbn Asâkir, Ebü'l-Kāsım. Târîhu medîneti Dımaşk. thk. Amr b. Garâme el-Amrevî. 80 Cilt. Beyrût: Dâru'l-fikr, 1415/1995.

İbnü'l-Esîr. Ebü'l-Hasen İzzeddîn Alî. Üsdü'l-gāäbe' fî ma'rifeti'Ṣ-Ṣahâbe. thk. Ali Muhammed Mu'avvaz-Âdil Ahmed Abdülmevcûd. 8 Cilt. Beyrût: Dârü'l-kütübi'l-ilmiyye, 1415/1994.

İbn Hacer el-Askalânî. Fetḥu'I-bârî şerḥu Șaḥịhi'l-Buhârî. thk. Muhibbüddin el-Hatîb v.dğr. 13 Cilt. Beyrût: Dâru'l-mea'rif, 1379.

İbn Hacer el-Askalânî. Telhị̂̂ül'-ḥabîr fî tahrî̀ci ehââîsi'r-Râfi'iyyi'l-kebîr. thk. Ebû Âsım Hasan b. Abbâs. 4 Cilt. Mısır: Müessesetü Kurtuba, 1416/1995.

İbn Hacer el-Askalânî. Lisânü'l-Mîzân. 7 Cilt. Beyrût: Müessesetü'l-a'lamî, 1390/1971.

İbn Hacer el-Askalânî. Tehžîbü't-Tehzîib. 12 Cilt. Hind: Matbaatü dâireti'l-me'ârif, 1326.

İbn Hacer, Ebü'l-Fazl Şihâbüddîn Ahmed b. Alî b. Muhammed el-Askalânî. Nüzhetü'n-naẓar fí tavzîni Nuhbeti'l-fiker. Thk. Abdullah b. Dayfullah. Riyâd: Matbaat-ü sefîr, 1429/2008.

İbn Hişâm. es-Sirretü'n-nebeviyye. thk. Mustafa es-Sekkā - İbrâhim el-Ebyârî - Abdülhafîz eşŞelebî. 2 Cilt. Mısır: Matbaatü Mustafa, 1375/1955.

İbn İshâk, Ebû Abdillâh Muhammed. Sîretü Ibn İshâk. thk. Süheyl Zekkâr. Beyrût: Dâru'l-fikr, 1398/1978.

İbn Kesîr, Ebü'l-Fidâ' İmâdüddîn İsmâîl. Tefsîrü'l-Kur'âni'l-'aẓîm. thk. Sâmî b. Muhammed es-Selâme. 8 Cilt. B.y. Dâru Tayyibe, 1420/1999.

el-iktisadi, Cerîdetü'l-Arabi'l-iktisâdiyyeti'd-düvelî. "Makâlât". Erişim 30 Eylül 2020. https:// www.aleqt.com/2017/08/27/article_1243076.html

Kurtubî, Ebû Abdillâh Muhammed b. Ahmed. el-Câmi' li-aḥkâmi'l-Kur'ân. thk. Ahmed elBurdûnî. 20 Cilt. Kâhire: Dâru'I-kütübi'l-Mısriyye, 1384/1964.

Mâtürîdî, Ebû Mansûr Muhammed. Te'vîlâtü Ehli's-sünne. thk. Mecdî Basellûm. 10 Cilt. Beyrût: Dârü'l-kütübi'l-ilmiyye,1426/2005.

Mâverdî, Ebü'I-Hasen Alî b. Muhammed. Tefsîrü'I-Kur'ân (en-Nüket ve'I-'uyûn). thk. Seyyîd b. Abdülmaksûd b. Abdürrahîm. 6 Cilt. Beyrût: Dâru'l-kütübi'l-ilmiyye, ts. 
Mizzî, Ebü'l-Haccâc Cemâlüddîn. Tehžîbü'I-Kemâl fî esmâ'i'r-ricâl. thk. Beşşâr Avvâd Ma'rûf. 35 Cilt. Beyrût, Müessesetü'r-risâle, 1400/1980.

Moğultay b. Kılıç. Ikmâlü (Žeyl 'alâ) Tehżîbi'I-Kemâl. thk. Âdil b. Muhammed, Üsâme b. İbrâhim. 12 Cilt. Kâhire: el-Fârûku'l-hadîsiyye, 1422/2001.

Mukātil b. Süleymân. Tefsîru Mukātil b. Süleymân. thk. Abdullah Mahmûd Şehhâte. 5 Cilt. Beyrût: Daru ihyâi't-turâs, 1423.

Mücâhid b. Cebr. Tefsîru Mücâhid. thk. M. Abdüsselâm Ebü'n-Nîl'. Mısır: Dâru'l-fikr, 1410/1989.

Müslim b. el-Haccâc b. Müslim el-Kuşeyrî. Șahị̣̂u Müslim. thk. Muhammed Fuâd Abdülbâkî. Beyrût: Dâru ihyâi't-türâsi'l-Arabî, ts.

Önkal, Ahmet. "Ebû Ubeyde b. Cerrâh". Türkiye Diyanet Vakfı İslâm Ansiklopedisi. 10: 249250. İstanbul: TDV Yayınları, 1994.

Râzî, Fahrüddîn Muhammed b. Ömer b. Hüseyn. Mefâtîḥu'l-ġayb. 32 Cilt. Beyrût: Daru ihyâi't-türâsi'l-Arabî, 1420.

Sa'lebî, Ebû İshâk Ahmed b. Muhammed. el-Keşfve'I-beyân 'an tefsîri'l-Ḳur'ân. 33 Cilt. Cidde: Dâru't-tefsîr, 1436/2015.

Süyûtî, Ebü'l-Fazl Celâlüddîn. ed-Dürrü'l-mensûr fi't-tefsîr bi'l-me'sûr. thk. Abdullah b. Abdülmuhsin et-Türkî. 15 Cilt. Kâhire: 1424/2003.

Süyûtî, Ebü'l-Fazl Celâlüddîn. el-itk $\underline{\text { ān }}$ fî 'ulûmi'I-Ḳur'ân. 7 Cilt. Suûdiyye: Mecmeu'I-Melik Fahd, ts.

Taberânî, Ebu'l-Kâsı Süleymân b. Ahmed b. Eyyûb. el-Mu'cemü'l-kebîr. thk. Hamdî b. Abdülmecîd es-Selefî. 25 Cilt. Kâhire: Mektebetü İbn Teymiye, 1415/1994.

Taberî, Ebû Ca'fer Muhammed b. Cerîr. Câmi'u'l-beyân 'an te'vîli âyi'l-Kuru'ân. thk. Abdullah b. Abdülmuhsin et-Türkî. 24 Cilt. Kâhire: 1422/2001.

Tirmizî, Ebû Îsâ Muhammed b. Îsâ b. Sevre. Süneni't-Tirmižî. thk. Ahmed Muhammed ŞâkirMuhammed Fuâd Abdülbâkî. 5 Cilt. Mısır, Şirketü Mektebeti ve Matbaati Mustafa, 1395/1975.

Vâkıdî, Ebû Abdillâh Muhammed. Megāzî.. thk. Marsden Jones. 3 Cilt. Beyrût: Dâru'l-a'lemî, 409/1989.

Zehebî, Ebû Abdillâh Şemsüddîn Muhammed b. Ahmed. Siyeru a'lâmi'n-nübelâ'. thk. Şuayb el-Arnaût ve dğr. 25 Cilt. Beyrût: Müessesetü'r-risâle, 1405/1985.

Zehebî, Ebû Abdillâh Şemsüddîn Muhammed b. Ahmed. Mîzânü'l-i'tidâl fî naḳdi'r-ricâl. thk. Ali Muhammed el-Bicâvî. 4 Cilt. Beyrût: Dâru'l-ma'rife, 1382/1963.

Zemahşerî, Ebü'l-Kāsım Mahmûd b. Ömer. el-Keşşâf 'an ḥakāa'iḳi't-tenzîl. thk. Abdurrezzâk el-Mehdî. 4 Cilt. Beyrût: Daru ihyâi't-turâs, ts. 
